\title{
REFLECTIONS ON GLOBALIZATION
}

\section{POLITICS, CULTURE, RHETORIC, GLOBAL WARMING: FROM LOCAL TO GLOBAL REALITIES}

\begin{abstract}
Donald V. Kurtz
The politics of global warming represents a dialectic of conservative and progressive agents that respectively deny the existence of global warming and believe it is an existential threat to humankind. This paper relies on ideas suggested by Antonio Gramsci to argue that culture conceived as a political tool provides a means to mitigate the risk of global warming. It reveals how conservative agents at the local level of human communities and governments have used culture as a tool to convince social categories in the United States that global warming is not a problem. Progressive agents fail to use the power of the culture concept to contradict conservative arguments and develop cultural practices that might enable mitigation. The failure of local level practices to mitigate global warming may stimulate the development of an alternative global form of government dedicated exclusively to mitigation to forestall an environmental and human catastrophe.
\end{abstract}

Keywords: politics, culture, rhetoric, Gramsci, hegemonic culturation, global warming, sciemocracy.

The Problem

If we do not change direction we are likely to end up where we are going (Ancient Chinese proverb)

By the middle of the twentieth century scientists were reporting that carbon dioxide (CO2), methane (CH4), nitrous oxide $\left(\mathrm{N}_{2} \mathrm{O}\right)$ and other noxious gasses were being trapped in the earth's atmosphere and creating a global greenhouse effect that was causing the planet to warm. Since then data that identify anthropogenically-induced global warming as an existential threat to humankind and its civilizations have expanded dramatically. Still, global warming and its abnormal climate patterns continue to increase (International Energy Agency 2018). The 2014 Assessment Report of the Intergovernmental Panel on Climate Change (IPCC hereafter) and the United Nations Convention on Climate Change that resulted in the Paris agreement, signed by representative of 195 of the world's governments, plead for the world's governments to take actions to mitigate global warming and forestall an impending global disaster (115 ratified the treaty in October, 2016, thereby putting it into force [Pinker 2018: 152]). Currently global temperatures are about $1.6^{\circ}$ Celsius above preindustrial levels. The goal of these hoped for governmental strategies is to prevent global temperatures from exceeding

Journal of Globalization Studies, Vol. 10 No. 1, May 2019 3-18 DOI: $10.30884 /$ jogs/2019.01.01 
$2^{\circ}$ Celsius above preindustrial levels. Two degrees Celsius is the IPCC benchmark, the tipping point, after which mitigation may be impossible and the planet too hot to support human life. To date these and other pleas for mitigation have had little effect. Without new ideas mitigation is not likely to occur in time, perhaps 30 to 40 years, before the $2^{\circ}$ Celsius threshold is breached and human life on the planet is challenged (Porter 2018).

\section{Introduction}

The late United States senator (and sociologist) Daniel Moynihan famously observed that, 'the central conservative truth is that it is culture, not politics, which determines the success of a society. The central liberal (progressive) truth is that politics can change a society and save it from itself' (cited in Friedman 2016: 110-111, parentheses added). Even though much of the data this paper relies on derives from events, populations, and practices common to the United States, 'progressive' and 'conservative' are not synonyms for 'democrat' or 'republican'. The latter are specific to the United States; the former has a more global connotation but remains, nonetheless, fraught with complicated political implications. To lighten the evocative load of these terms and fit them to the argument of this paper I rely on a single, sharper distinction. Progressives believe that anthropogenic global warming is a reality that requires political action for mitigation. Conservatives largely deny the existence of global warming, but those that do accept as a modicum of fact that global warming may exist believe that market forces, not government interventions, will be sufficient to rectify the problem.

Moynihan's distinction between these 'truths' injects a new factor into the global warming debate: culture. In this paper I shall interrogate how the cultural dimensions of the conservative and progressive dialectic that distinguishes current American environmental politics influences the evaluation and possible mitigation of global warming. It will be shown how the 'conservative cultural truth' has trumped the 'progressive political truth'. I will argue that the conservative and progressive politics and attendant rhetoric materialize the dialectic of culture and politics, of conservative and progressive values and agencies, regarding global warming that to date has served best the interests of believers of the conservative truth. I postulate that this will be reversed only when a progressive politics emerges that recognizes the power of culture to change the values and practices of social categories in the United States and elsewhere globally which currently deny global warming and impede its mitigation.

The attitudes and practices of the citizens and government of the United States are especially relevant to this debate. The United States is among the world's worst environmental polluters. Its current conservative policies have diluted the powers of the government's Environmental Protection Agency and it is the only government to withdraw from the Paris agreement. The proliferation over the last 40 or so years of sciencebased books, articles, and arguments that demonstrate the threat global warming poses to humankind and its civilizations has made little difference in these postures. Mitigation has been negligible. 
Two propositions may be extrapolated from Anthony Giddens's (2011) recent book The Politics of Climate Change that are relevant to these issues and the following arguments. First, a politics of global warming does not exist. Second, a politics to mitigate global warming will have to be qualitatively different from any politics that exists currently.

I will negate Giddens' first proposition and demonstrate how a politics of global warming that is peculiar to 'local level' communities and populations in the United States (and presumably other nations) has been created and deployed to reject values and practices related to mitigating global warming. Regarding his second proposition, there will be suggested a new form of global government, a sciemocracy (Kurtz and Fustes 2016), to engage mitigation strategies if 'local level' governance practices fail.

\section{Local Level Cultural Politics}

Giddens's (2011: 4) first proposition contends that no politics exists currently to respond to global warming because 'states' have failed to execute mitigation policies. The idea that states engage in politics obscures the nature of politics in general as well as the politics to mitigate global warming. The distinction I draw between the state and politics is not merely semantic. It represents a qualitative distinction between an abstract, largely symbolic, static political structure (state) and a multipotent agency constituted of human beings that contest for divergent goals (politics). Attributing politics to the state in effect anthropomorphizes an abstraction and denies the consequences of a human agency that draws its power from the peculiar composition of a state.

I think of the state as an incorporeal symbolic entity constituted of abstract offices vested with powers that can be used only by the incumbents of those offices (Kurtz 1993, 2001, 2006). As such the state has nothing to do with politics. The failure to mitigate global warming is not because the state has failed to act. It is a failure of the incumbents of state offices of the world's governments and other contesting agencies to agree on the cause and/or existence of global warming. The politics these agents engage in, not the state, will determine whether mitigation occurs. Consideration of this politics requires attention to the power relationship - replete with dirty tricks, lies, deceits, treasons - between cultural processes and human agency that are ignored in discussions of global warming.

Until the advent of cultural studies programs in the 1980s, the anthropologists (Americans primarily) claimed ownership of the culture concept. To simplify a complex relationship, adherents to two anthropological schools of thought have debated for decades the nature of culture (Rodseth 2018). One school was committed to an idealist cultural relativism that sanctified the ethnographic distinctiveness of cultural differences and relied on particularistic and hermeneutic analyses of discrete societies. Adherents to the other school were dedicated to a more scientific (always a bit weak), generalizing approach to culture. They relied on materialist, quasi-Marxist ideas to demonstrate the regularities, especially in social organizations, that accounted for similarities across ethnographically depicted types of societies. As with the distinction between state and politics, the difference between relativist particularism and generalizing materialism is 
more than semantic. It establishes methodologies that are qualitatively different and have real-world consequences for how one approaches a problem.

For example, a task force appointed by the American Anthropological Association developed a document, Humanity and Climate Change (Fiske et al. 2014), to guide anthropological research on global warming. This document conflates the idea of culture defined as a web or meanings unique to discrete societies and a particularistic cultural relativism with values inherent in a functional paradigm. It also suggests that because of their skills and knowledge of culture anthropologists should rely on a triage to help afflicted societies adapt to the impact of global warming and maintain their cultural integrity. There is nothing inherently wrong with this methodology; it reflects a sensitive, compassionate concern with the consequences of global warming. But this model also denies the idea of culture any role or power in mitigating the existential threat global warming represents.

Ideas spawned by Antonio Gramsci provide an alternative methodology that defies Moynihan's distinction and infuses culture with the power to change aspects of the human condition. This paper relies on the application of a theoretical hegemonic culturation, a neologism (Kurtz 1996b, 2001, 2004) I derive from Antonio Gramsci's ideas of hegemony and culture, to suggest a politics of global warming. I will engage Gramsci's ideas of hegemony and culture to demonstrate how they influence strategies and practices related to global warming. Curiously, conservatives already, unwittingly given its Marxist bias, have used this model successfully to trump opposing progressive arguments and convince significant categories of the American public that global warming is not a problem.

\section{Hegemony and Culture}

Hegemony, arguably Gramsci's most important idea, refers to an intellectual, moral, and political leadership - individuals, groups, organizations - hegemons as I think of them, to induce social changes. Hegemony always involves a dialectic of contradictory entities. Gramsci identified two types of contradictory hegemons: traditional and organic (1971: 55ff; Kurtz 1996a: 103-106). Gramsci's traditional hegemons are embodied in the capitalist bourgeoisie and its allies, for example, the Catholic Church. Regarding global warming, traditional hegemons represent the interests of conservative incumbents of political offices, special interests that support them, energy cartels, think tanks, and 'merchants of doubt', scientists and spokespersons paid by global warming deniers to dissuade mitigation (Orestes and Conway 2011). Gramsci's organic hegemons represent the interests of the proletariat. Regarding global warming, organic hegemons are the progressives in government and non-government environmental organizations, including most of the world's qualified scientists that currently lack the power to mitigate global warming.

In this paper the politics of traditional and organic hegemons is displayed in the dialectics that pits skeptics and 'big energy' spokespersons (traditional) that deny global warming against scientists and environmentalists (organic) that would mitigate it. The hegemons involved in the dialectic are crucial to the instantiation of Gramsci's most 
powerful idea of culture, for they are charged with infusing people with ideas to gain their support, alter their relations of cause and effect, and establish alliances widely to advance their agendas (Gramsci 1971, 2007; Kurtz 1996a: 106).

Gramsci says, 'I give culture this meaning: it is the exercise of thought, the acquisition of general ideas, the habit of connecting cause effect ... enlivened by (political) organization (that) we (bring) to every political activity' (Gramsci 1917; Buttigieg 1987: 20; Cavalcanti and Piccone 1975: 44, italics and parentheses added). Gramsci's notion of culture is not a relativistic construct. It is a hegemonically directed process that influences and determines both idealist (thought and ideas) and materialist principles (what we do and its consequences). The quotidian ideas (ideologies) and habits (cultural practices) that animate cause and effect relationships in human agency are created and established among a population hegemonically. Leaders determine the ideologies and materialist practices they desire to instill in their existing and potential followers. Gramsci's idea of culture applies to malleable organizations, the configurations of which across space and time 'are continuously in construction, deconstruction, and reconstruction' evoked by contesting forces - political agents (hegemons) seeking to carry the day with their beliefs and practices (Wolf and Silverman 1982: 387-388; Kurtz 1996b: 209; Crehan 2002: 17). These processes are the temporal and spatial outcomes of what I refer to as a hegemonic culturation, a process that engages leaders and their supporters dialectically in a contest either to change or sustain a notion of cultural that complies with their values.

Hegemonic culturation addresses how ideologically grounded ideas that are materialized as habits that connect cause and effect relations in human agency are disseminated among a population by political agents (Kurtz 1996b). Hegemonic culturation relies on a political agency with the power to formulate and inculcate a culture that will change people's shared meanings and patterns of cause and effect. In Gramsci's thinking, as we shall see, culture understood as ideological constructions and materialized practices - why and how people do what they do - looms large as an anthropogenically motivated force to invoke populations to scale their cause-effect relationships to their social and environmental realities and either mitigate global warming or deny its existence. To date hegemonic culturation has been more effective in denying that global warming represents an existential threat to humankind than it has in supporting mitigation.

For example, many people in the US Midwest rust belt and oil polluted regions of the American south felt they lost their honor and dignity as their jobs increasingly were jettisoned overseas and government programs and regulations subverted and abased their sense of self-worth (Hochschild 2016a; Vance 2016). Indeed, in an apparent contradiction to Moynihan's truth that politics can 'save a society from itself', Hochschild (2016a, 2016b) discovered that people in the Louisiana bayou believe that their honor and traditional culture was lost due to progressive government practices. As an example of this presumed deprivation consider the following:

Mike, a Louisiana oil rig worker struggled to climb out of poverty. At the entrance to the gate of the middle class he felt he had been slapped in the face. Progressive 
movements from the 1960s supported blacks, women, sexual minorities, immigrants, refugees... Democrats and Media liberals were now ridiculing people like him as ignorant, backward, rednecks. It mattered little to him that Donald Trump would not reduce the Big government he wanted cut. Trump, he felt, would switch off the marginalization machine and restore the honor of his kind of people, of himself. Like other of his white neighbors Mike was foursquare for Trump: that's how deeply his pride was injured and a measure of how much that galled him (Hochschild 2016b: 25-26).

Hochschild's (2016a: 251) informants in the polluted sump much of southern Louisiana represents are the epistemological foundation of her conclusion that, 'the more polluted a state is, the more likely it is to vote (conservative) ... and think the United States is... overreacting to the issue of global warming' (Ibid.: 253, parenthesis added). Hochschild left her field work feeling often that she and her 'new friends... lived not only in different regions but in different truths' (Hochschild 2016a: 255).

Gramsci does not provide details of strategies by which organic hegemons develop and deploy practices to create a different culture. But, perhaps because of this talent for linguistics and philology, his writings are laced with implications of language and culture, often cryptic, as revolutionary tools: 'Every language contains the... conception... of a culture' (Gramsci 1971: 325) ... 'and is in reality a multiplicity of facts more or less organically coherent and coordinated' (Ibid.: 349). Hegemons responsible for creating such a cultural world view 'can no longer rely ... on feelings and passions (they) must participate in practical life, as constructor, organizer, "permanent persuader" and not just a simple orator' (Ibid.: 10). Rhetoric, political talk expressed through various vernaculars to persuade others, is a reasonable interpretation of what Gramsci is implying.

F. G. Bailey (1983) points to a caveat in the expectation that rhetoric understood as 'organically coherent and coordinated' (by) 'permanent persuaders' necessarily results in reasoned thinking and positive outcomes. Bailey concedes that reason plays a role in rhetoric. But because reason is cold, calculating, and dull it provides little impetus to move people toward a goal. This is accomplished by a passionate rhetoric that imputes meaning to situations which reason cannot and thus has the power to move people to action. Passions, for Bailey, are tactics in larger political strategies.

Bailey argues that while the skillful use of passion in the pursuit of political goals is often the difference between success and failure, the tactical expenditure of passion is necessary to reach a modicum of reason which remains the only way to resolve once and for all problems of the real world. Still, reason has some success in resolving problems. Its efficacy is most profound when it is used to confront abominations, concoctions of material and ideological contingencies, such as infuse the global warming debate, which are so bewildering to so many that they remain unmentionable ides that cannot be brought into the open and discussed rationally.

Abominations lead to acrimonious debates and allow passions to run amok. Passionate rhetoric, therefore, is inappropriate for confronting an abomination; it risks confusing issues even more. The resolution of an abomination, such as the existential threat global warming poses, begs for reason. Abominations provide the platforms that reason 
requires allowing agents to introduce sophisticated codes and vernaculars that reveal the abomination and permit new ideas and strategies to enter the arena, deconstruct the abomination, realign the cultural practices of a population, and establish an alternative cultural formation.

Rhetoric is essential to politics, including the politics of global warming. But by itself rhetoric is insufficient. It requires an infrastructure to enhance delivery, a code or style in vernaculars fitted to discrete audiences whose cultures need to be changed or reorganized to confront the abomination global warming portends. Donald Trump's vulgar rhetoric attracted a 'base' that enabled his election as president of the United States with expectations he would, among other acts, withdraw from the Paris climate agreement and eliminate the Environmental Protection Agency. His rhetoric was unique in its presentation, but it was merely the most recent result of conservative strategies that were intentionally initiated decades ago and finessed more recently in purposeful strategies to debunk progressive rhetoric and change the culture of select populations in the United States.

\title{
Hegemonic Culturation: Conservative Praxis ${ }^{1}$
}

\author{
Politics is downstream from culture. I want to \\ change the cultural narrative. \\ Andrew Breitbart (cited in Green 2017: 86)
}

Beginning in the 1960s at their annual retreats political conservatives and their supporters began to plot a hegemonic culturation to change the culture of America's voting public and replace a progressive vision of America with a conservative vision. At about the same time high school and college students were being recruited by the Young American's Foundation to learn the proper vernaculars to develop and deploy conservative ideas in the future. Eventually these hegemons discovered the power of frame analysis (Goffman 1974), mental structures that shape the goal we seek, our social policies, and the institutions we create to carry them out; 'framing is social change' (Lakoff 2014: xi).

Conservative intellectuals, largely Dr. Frank Luntz, tested and developed a rhetoric that framed phenomena relative to a conceptual framework that favored a conservative point of view. Luntz (2007: 263) points out, 'By defining an issue or a cluster of issues as a part of a metaphorical "culture" you can lend it new weight and seriousness'. For example, clean coal is an oxymoron. But every time a progressive commentator rejects verbally the idea of 'clean coal' the oxymoron is reinforced factually by its negation. Progressive concerns about 'drilling for oil' were reframed as 'exploring for American energy'. A progressive proposal to tax inheritance of the wealthy became the 'death tax!' Luntz advised the Bush administration to replace 'global warming' with 'climate change' because it was less threatening.

Luntz developed training manuals replete with strategies intended to create a specific culture among selected social categories of the American public. He demonstrated that 'words matter' and are important strategic components in both applied and theoretical contexts. These strategies reduced the politics of global warming to a dissembled 
hypertrophic rhetoric and self-indulgent scientific ignorance ('I'm not a scientist' remarked by several conservative United States representatives; a snowball held by a conservative senator on the U.S. senate floor as proof global warming does not exist; President Trump's insistence, it is a 'hoax!') that forestalled any serious mitigation. Over the last 40 or so years conservative hegemons purposefully engaged strategies to restructure the culture of that sector of the American public whose votes progressive politicians had taken for granted for decades.

For wealthy conservatives (Koch brothers, DeVos family, the Mercers) winning a presidency became a secondary consideration. Instead they channeled billions of dollars to establish and expand local level infrastructures that caused progressive legislators, largely through redistricting strategies, to lose thousands of seats in local legislatures and secure conservative control in 33 of the 50 states of America. Conservative rhetoric that emanated from these and other sources created a clutch of ideas and practices that infused the cultural values of sufficient numbers of people, such as those in America's rust belt and oil polluted southern states, to relegate global warming to a nearly nonexistent concern on their 'to do' list.

To sustain this cultural advantage the conservative established institutes and think tanks - Heritage and Reason Foundations; Manhattan, American Enterprise, Acton, and Claremont Institutes: The Family Research Council, and many others - to promote hegemonically their cultural strategies. Today they support over 1500 politically conservative and evangelical radio shows (Rush Limbaugh). They built and staffed TV studios (Fox), websites and news outlets (Breitbart News, Drudge Report) to provide agents sinecures for their writings and rhetoric. They tout positive reviews of conservative political thought (Claremont Review of Books). They hire intellectuals and scholars (Dr. Frank Luntz) and research assistants to develop their ideas in their think tanks. They support cadres of conservative students (Young American's Foundation, campus republicans) to challenge ideas expounded by less conservative educators. They establish university professorships and provide accommodations for them to write on issues from a conservative perspective. Their legislators defund universities and programs they perceive to be too progressive. They purchase thousands of conservative books to keep them on the best seller lists (Hillbilly Elegy?) and continue to write others (God's Green Earth; The Fractured Republic). They make movies (Clinton Cash, Hillary: The Movie) and back television shows (Duck Dynasty) to inculcate their ideas among the larger public. They purposefully misrepresent progressive evaluations of global warming and threaten mitigation advocates, such as Orestes and Conway (2011), by phone and hate e-mails. The result is an integrated cultural pattern to which conservatives conform and thereby control local level politics.

Conservatives identify progressives as congeries of wastrels (47 per cent of the American public according to 2008 presidential candidate Mitt Romney) who expect to live off government doles or refuse to help themselves (President Trump after a category five hurricane devastated Puerto Rico in 2017). Conservatives disrespect the separation of church and state prescribed by the United States Constitution (Vice-President Pence); money now represents an accepted vernacular in our political discourse (United 
States Supreme Court); the materialization of progressive values (welfare, food stamps) diminishes individual worth (Vance 2016).

In effect conservative hegemons engaged a hegemonic culturation through pragmatic practices to develop a rhetorical infrastructure replete with disingenuous information and dirty tricks to craft and scale a voting population with conservative cultural values ready to trivialize progressive evaluations of the threat posed by global warming. The production of this culture was enabled by a rhetoric that inseminated and reproduced the DNA of President Ronald Regan's 1981 declaration that, 'government is the problem', not the solution, to global warming and other perceived social ills. Progressives no longer find a mental market place for their ideas among these categories of the American and global public.

\section{Hegemonic Culturation: Progressive Praxis}

An ounce of civet, good apothecary to sweeten my imagination.

(King Lear, Act IV, scene 1)

By 1997 the progressives were aware that the promotion of their ideas through think tanks and media outlets was woefully inadequate compared to conservative facilities (Kallick 2002). Progressive hegemons have sound and workable ideas regarding how to mitigate Global Warming (Kress and Stine 2017; Hawken 2017; Scientific American 2017/2018). They do not lack material resources. Their think tanks and research institutes are supported by some deep pockets (George Soros [comes close to matching the Koch brothers in dollars dedicated to their interests], Tom Streyer [founder, New Generation Action Organization], Richard Branson [Chairman, Virgin Groups Ltd], Silicon Valley billionaires). They have political supporters, often a minority, in various levels of local, state, and federal governments, and the United Nations. This is much the same space conservatives occupied 40 years ago, until President Ronald Regan and his administration began to deploy conservative cultural strategies and gradually eviscerate progressive cultural ideas and practices.

Progressive hegemons have not been able to formulate a unified cultural message to address the abomination of global warming or develop an effective agency to challenge conservative hegemons. The dominant progressive agency has been dedicated to an identity politics related to specific social categories - black, gays, women, Hispanics, the poor - and specific problems related to each category - racial, gender and ethnic equality, job training, voting rights, gay marriage, paths to citizenship. The politics of responding to the expectation of each category and fending off conservative objections has spread progressive resources thin, depleted their rhetorical energy, and created contradictions that are not easily resolved (Lilla 2017).

Progressive hegemons lack the imagination conservatives bring to the idea of culture and its rhetorical consequences. They do not understand why their rhetoric fails to regain the constituencies lost to a purposefully planned and applied conservative rhetoric. Senator John Kerry grasped this failure when he asked. '.. where's our Frank Luntz?' (book jacket, hardbound copy, Luntz 2007). In a 2014 revision of a 2003 publication Lakoff iterated that the simplest strategy to establish progressive hegemony over 
global warming is to copy what the conservatives have done over the past 40 years. This represents a flat line, not a learning curve.

The words conservatives use to frame their message - regulations are bad, taxes an unfair imposition, science cannot be trusted, global warming is a hoax - derive from ideas Luntz proposed in his training manuals to give conservatives a political advantage (Lakoff 2014: 20). Conservative hegemons have become Gramsci's 'permanent persuaders', progressive hegemon his 'simple orators', unable to realign rhetorically or in practice to challenge conservatives. Ironically, Luntz's ideas are more in concert with Gramsci's notions of how to craft a cultural message appropriate to a constituency than are those of progressive hegemons.

A progressive vernacular exists: taxes are dues you pay to live in a democracy that offers opportunity and provides roads, schools, the power grid; regulations are protections against injustices and health problems induced by environmental pollution (Lakoff 2014). Lakoff excels at pointing out how conservatives changed the language of politics and use words that 'draw you into their world view' (Ibid.: 2). He is less successful in providing terse, effective alternative tropes. Lakoff is Gramsci's 'simple orator', Luntz is his 'permanent persuader'.

Instead of trying to compete with conservatives in a rhetoric they seem to own, progressives might take note of the fact that not all among the conservative United States evangelical community are irrevocably hostile to mitigating global warming (Callison 2014). Evangelicals account for 30,000,000 Americans, one quarter of the American electorate, that are members of the National Association of Evangelicals. They are not as ideologically monolithic as the rust belt and bayou evangelicals depicted by Hochschild and Vance. Progressives might consider altering their rhetoric to develop a vernacular that is acceptable to select evangelicals and allow an alliance favorable to mitigation.

Some evangelicals reject utterly the science related to global warming. But Creation Care represents an evangelical movement, 'still largely nascent', of young conservatives with 'green voices' that call for care of the environment in biblical terms (Callison 2014: 131). They are united in 'blessing the facts', that is, evaluating global warming simultaneously in scientific and biblical vernaculars that invoke 'environmental stewardship', 'tending the garden', 'biblically mandated care for the poor', and protecting 'God's handiwork'.

Science is not a dirty world among many of these evangelicals. But its message must be cast in a vernacular that accommodates God's plan for humankind. Leaders of the Creation Care movement, Richard Cizic for example, assert that it is not a fringe movement; 'it is coming from and targeted at the traditional conservative heart of the movement' (Ibid.: 136). In an interview with a conservative Fox news commentator who intended to defame climate scientists Cizic responded, 'Yes, I trust these scientists'. When the commentator queried how many people 'will listen to you?' Cizic responded, ‘Thirty million' (Ibid.: 150).

Calvin DeWitt, an American environmental scientist and committed evangelical, summed up the stance of Creation Care: 'Our ultimate purpose is to honor God as the creator in such a way that Christian environmental stewardship is part and parcel of 
everything we do' (Ibid.: 153). The movement is not attempting to change the minds of those who actively contest global warming. Instead, their hegemonic culturation strategy is 'aimed at people who have not given the issue time or attention, or had it explained to them as an issue that connects them to Christian responsibility and morality' (Ibid.: 137-138).

The creative care movement is home to green evangelicals, most of whom are young adults. The 2017 summer science march in Washington D.C. was organized by young scientists, pre-docs, post-docs, and graduate students ('Big names' were not easily visible). These two demographic cohorts may not be a natural fit for leadership in the mitigation of global warming. But they share a critical value that is not addressed in conservative rhetoric: care of the planet and empathy with its inhabitants. Young green evangelicals want to preserve God's handiwork. Young scientists want to mitigate the abomination of global warming. These concerns might be sufficient for each to listen to the other's vernacular, reconsider their differences, and conjoin ideas and practices that can be parlayed into a better secular and evangelical coexistence. They might even find refuge in a sciemocracy.

\section{Global Politics and a Sciemocracy}

Giddens's (2011) second argument, that a politics of global warming must be radically different from any that exists currently, apparently implied an idea whose time has come. As noted, Kurtz and Fustes (2016) already have modeled a sciemocracy that complies with Giddens's admonition. Without modeling their ideas Bonneuil and Fressoz (2016), West and Karsten (2017), and Biermann (2017) also have suggested that mitigation will require some new kind of political organization, preferably embedded in the United Nation. This idea has been endorsed by The World Trade Organization, the United Nations Development Program, and, to date, the governments of Brazil, France, Germany, New Zealand, Singapore, and South Africa (Bierman 2017).

Recall that the Paris agreement relies on the voluntary compliance of its 195 signatories (as noted, 40 nations, have not yet ratified the agreement [Pinker 2018] and apparently intend to ride free on the compliance of others). When Ban Ki-Moon, then secretary general of the United Nations, was asked if voluntary compliance with the stipulations of the Paris agreement was feasible he replied, 'there is no Plan B if the deal falls apart' (Davenport 2015: 18). In that contingency the sciemocracy (or something similar) might provide that 'Plan B'.

To comply with Giddens's argument for an entirely new form of government Kurtz and Fustes (2016) argue that the sciemocracy (see Fig. 1) should exist independent of the United Nations to avoid the controversies that best the organization. But it must interface with the world's governments to enact and deploy mitigation strategies. The sciemocracy therefore will not be divorced entirely from the local level progressive-conservative politics that currently prevail. But if, over the next several years, local level politics has not provided the necessary mitigation the conditions of humankind may be sufficiently desperate to make the sciemocracy acceptable to the world's most conservative global warming skeptics. The following is an abbreviated depiction of the sciemocracy model that appeared in Kurtz and Fustes (2016). 


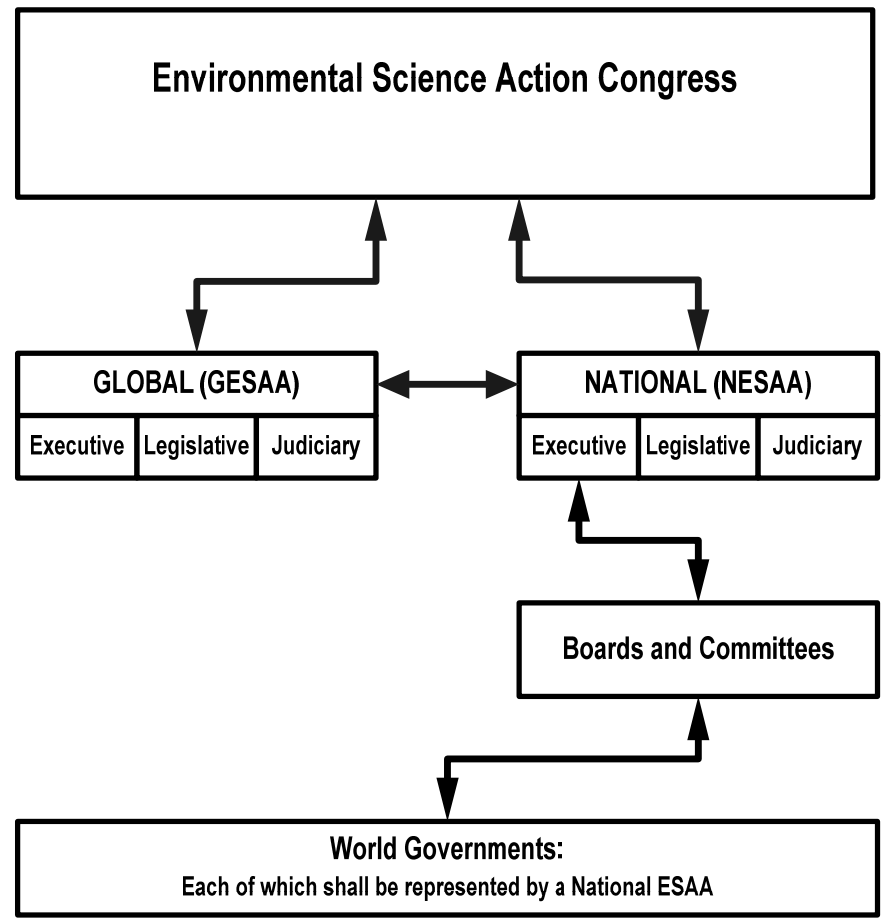

Fig. 1

Source: Kurtz and Fustes 2016

Preamble: The rationale for the sciemocracy is based on two propositions. First, the institutional and technological mechanisms to mitigate global warming do not exist (Sokona 2014: 2 [co-chair of the IPCC]). Second, the politicians that constitute the world's governments are neither qualified nor capable of developing mitigation strategies in the relatively short time we have available to avert disaster.

Institutionalization and function: The establishment and success of the sciemocracy will rely on the ability of the world's scientists and population to agree that enabling a sciemocracy is the best hope for the survival of humankind and its civilizations. Precisely how this might occur is difficult to predict. But previous experiences, the retaliation, for example, of the colonies that became the United States of America, against taxation without representation, suggest a format.

A world population facing a dire future under adverse environmental circumstances begins to coalesce around the idea of a sciemocracy and approaches the world's scientific community for help. The scientific community comes together and persuades the world's population to hold an enabling referendum that, with an approval of 51 per cent of the world's voters, allows them to establish the sciemocracy. Assuming that is successful, the scientists of the world's nations shall convene and elect from among themselves the members to the offices of the executive and legislative branches of the Congress. The scientists to staff the Congress should be selected primarily from among 
those who have been or continue to be active in the IPCC and other agencies and institutions committed to mitigation.

Organization: The sciemocracy should consist of an Environmental Science Action Congress (the Congress hereafter, see Fig. 1) that is constituted of two mutually interactive bodies: a Global Environmental Science Action Assembly (the Global ESAA hereafter) and a National Environmental Science Action Assembly (the National ESAA hereafter). Each assembly should be staffed with accredited, expert scientists. The National ESAA should be representative of each of the world's participating nations. It should articulate with the Global ESAA and present to that body issues and ideas for mitigation that emanate from the world's governments.

National ESAAs should be independent but, through their own executive, legislative, and judicial offices, interface with both the Global ESAA and governments which each National ESAA represents. The National ESAAs will cooperate and negotiate through permanent and ad hoc committees, review boards, and appropriate national judicial bodies with the Global ESAA and world governments on policies related to global warming. Committees and advisory and review boards shall be constituted of National and Global ESAA representatives to assure interface with world governments on issues related to global warming.

Practice: The primary priority of the sciemocracy shall be to secure the funds necessary for mitigation (Piketty suggests five per cent of global gross domestic production (GDP) to ward off an environmental catastrophe [Piketty 2014: 569]). The Global ESAA shall acquire administrative budgetary powers over funds allocated through taxes from the nations under the environmental jurisdiction of the Congress and, until that is secure, pledges from private foundations, organizations, and benevolent billionaires (Soros, Streyer, and Branson) dedicated to mitigating global warming.

An office of the Independent Reviewer, other review boards, and a judiciary of the National ESAA should be established in each nation and maintain affiliations with the International Court of Justice, the Hague. These boards should oversee the policies and practices of the Congress. The office of Independent Reviewer should be vested with the power to mediate and, if necessary, arbitrate, possibly by the United Nations armed forces, resolutions to disagreements. National judiciaries established in each nation should provide appellate services to litigants. The International Court, the Hague, should provide the ultimate source of appeal. Other advisory boards should be available to monitor the practices and technologies for mitigation and interdict unforeseen, deleterious impacts on human societies.

The core principle of the sciemocracy should rely on the basic rule of risk management: the people most knowledgeable and capable of controlling the risk should be put in charge of managing the risk. Doctors treat illnesses; carpenters do not. Ergo, bona fide scientists, not politicians, need to be responsible for mitigating the risk global warming poses to humankind and its civilizations.

Naysayers may argue it would be impossible to establish a sciemocracy or take too long. Recall that after a fledgling cabal of colonists in North America declared independence from England in 1776 it took only 12 years through a war and primitive communication to establish the United States of America. The United Nations was planned 
and operational within five years. Examples of rapid development abound. 'There is no reason other than indulgent self-interest to impede the establishment of a sciemocracy' (Kurtz and Fustes 2016: 16).

\section{Conclusion}

There is a crack in everything; that's how The light gets in Leonard Cohen

Global warming represents the slow trudge of an existential threat to the survival of humankind and its civilizations. Estimates by climate scientists of how long the planet will continue to heat until it comes too hot for human habitation vary. Relying on numbers to represent the time frame within which global warming must be mitigated impedes mitigation; numbers are easily shunted aside or pushed back. Identifying global warming as an imminent threat that will impact negatively these generations' grandchildren and great grandchildren may be a better way to personalize the urgency of mitigation.

Most discussions concerned with mitigation rely on technological or political economic solutions: reducing greenhouse gas emissions, producing more fuel-efficient vehicles, wind and solar farms, carbon taxes, market forces, and so forth. The idea of intentionally changing the culture of populations, as Antonio Gramsci suggests, to alter human environmental relations is a novel approach. Conservatives at the local levels in the United States have relied on this strategy to gain a significant edge in the debates related to global warming; they have successfully convinced large categories of the American public that it is not a threat. Progressives who are most committed to mitigation have not grasped the power of culture to convince people otherwise. They need to reconsider the identity politics they currently favor and frame a message regarding a cultural response to global warming that is meaningful to their constituency.

A sciemocracy may provide the institution to mitigate global warming. But the resistance of conservatives to any government intervention makes this a reality only when it might be too late to insure mitigation. A melding of the vernaculars and cultures of young scientists and 'green' evangelicals into a unified rhetoric and practice dedicated to saving humankind and its civilization might illuminate peoples' imaginations and engender a response that successfully mitigates global warming and forestalls a catastrophe. Time will tell!

\section{Acknowledgments}

My thanks to Hans Claessen, John Driggers, Gabriel Ferreyra-Orozco, Mary Hauser, Grace Keyes, Thom Keyes, and James McDonald for comments that made this paper better.

\section{NOTE}

${ }^{1}$ The following discussion derives largely from Kallick (2002), Luntz (2007), Callison (2014), Lakoff (2014), Green (2017), and Green and Saul (2018). 


\section{REFERENCES}

Bailey, F. G. 1983. The Tactical Uses of Passion. Ithaca: Cornell University Press.

Biermann, F. K. 2017. The Emerging Debate on the Need for a World Environment Organization: A Commentary. URL: https://www.reserchgate.net/publication/24089703_The_ Emerging_Debate_on_the_need_for_a_World_Environment_Organization_ A_Commentary.

Bonneuil, C., and Fressoz, J.-B. 2016. The Shock of the Anthropocene: The Earth, History, and Us. Transl. by Fernbach, D. Verso: London.

Buttigieg, J. A. 1987. Antonio Gramsci's Triad: Culture, Politics, Intellectuals. Center for Humanistic Studies. Occasional Paper, no 10. University of Minnesota.

Buttigieg, J. A. 1992-2011. Antonio Gramsci: Prison Notebooks. In 3 vols. New York: Columbia University Press.

Callison, C. 2014. How Climate Change Comes to Matter. Durham: Duke University Press.

Cavalcanti, P., and Piccone, P. (eds.) 1975. History, Philosophy, Culture in the Young Gramsci. Saint Louis, MO: Telos Press.

Crehan, K. 2002. Gramsci, Culture and Anthropology. London: Pluto Press.

Davenport, C. 2015. In France, Consensus on a Need to Lower Carbon Emissions. Sunday, December 13. New York Times, National Section CLXV (57079): 1-19.

Fiske, S. J. et al. 2014. Changing the Environment: Anthropology and Climate Change. Final Report of the AAA Global Climate Global Task Force. December. Arlington, VA: American Anthropological Association.

Friedman, T. L. 2016. Thank You for Being Late: An Optimists Guide for Thriving in the Age of Acceleration. New York: Farrar, Strauss, and Giroux.

Giddens, A. 2011. The Politics of Climate Change. Cambridge UK: Polity Press.

Goffman, E. 1974. Frame Analysis. Cambridge, MA: Harvard University Press.

Gramsci, A. 1917. Philosophy, Good Will, and Organization. Avanti 24 (See Buttigieg 1987).

Gramsci, A. 1971. Selections from the Prison Notebooks of Antonio Gramsci. Ed. and transl. by Hoare, Q. and Nowell Smith, G. New York: International Publishers.

Green, E., and Saul, S. 2018. In Deals and Donations, Conservatives Influenced the Hiring of Professors. New York Times, Section A. p. 10.

Green, J. 2017. Devil's Bargain. New York: Penguin Press.

Hawken, P. (ed.) 2017. Drawdown: The Most Comprehensive Plan Ever Proposed to Reverse Global Warming. New York: Penguin.

Hochschild, A. R. 2016a. Strangers in Their Own Land: Anger and Mourning on the American Right. New York: The New Press.

Hochschild, A. R. 2016b. Donald Trump in the Bayou. URL: http://www.iea.org/newsroom/ news/2018/March/global-energy-demand-grew-by-2.1-in-2017.

Kallick, D. D. 2002. Progressive Think Tanks: What Exists, What's Missing? Report for the Program on Governance and Public Policy. Open Society Institute. New York. URL: https//:www.Opensocietyfoundation.org/sites/default/files/progress_thinktanks.pdf 
Kress, W. J., and Stine, J. K. (eds.) 2017. Living in the Anthropocene. Washington, D.C. Smithsonian Books.

Kurtz, D. V. 1993. A Reconceptualization of the Anthropomorphised State and the Centrality of Political Agency in State Formations. Political and Legal Anthropology Review 16 (1): 16-30.

Kurtz, D. V. 1996a. Hegemony and Anthropology: Gramsci, Exegesis, Transformations. Critique of Anthropology 15 (2): 103-135.

Kurtz, D. V. 1996b. Hegemonic Culturation and Work in State Formations. In Claessen, H. J. M., and Oosten, J. G. (eds.), Ideology and the Formation of Early States (pp. 278-297). Leiden: E. J. Brill.

Kurtz, D. V. 2001. Political Anthropology: Paradigms and Power. Boulder: Westview.

Kurtz, D. V. 2004. The Evolution of Politics and the Transition from Political Status to Political Office. Social Evolution and History 3 (2): 150-175.

Kurtz, D. V. 2006. Political Power and Government: Negating the Anthropomorphized State. Social Evolution and History 5 (2): 91-111.

Kurtz, D. V., and Fustes, M. 2016. The Politics of Global Warming: Sciemocracy and the Rescue of the Kobayashi Maru. Journal of Globalization Studies 7 (1): 2-29.

Lakoff, G. 2014. Don't Think Like an Elephant: Know Your Values and Frame the Debate. Vermont, White River Junction: Chelsea Green Publishing.

Lilla, M. 2017. The Once and Future Liberal: After Identity Politics. Harper Collins: New York.

Luntz, F. 2007. Words that Work: It's Not What You Say, It's What People Hear. New York: Hyperion

Orestes, N., and Conway, E. M. 2011. Merchants of Doubt: How a Handful of Scientists Obscured the Truth on Issues from Tobacco Smoke and Global Warming. New York: Bloomsbury Press.

Piketty, Th. 2014. Capital in the Twenty-First Century. Transl. by A. Goldhammer. Belknap Press of Harvard University. Cambridge Massachusetts.

Pinker, S. 2018. Enlightenment NOW: The Case for Reason, Science, Humanism and Progress. New York: Viking.

Porter, E. 2018. Pulling Punches in the Climate Change Fight. New York Times, 24 January, Section B1, pp. B3-4.

Rodseth, L. 2018. Hegemonic Concepts of Culture: The Checkered History of Dark Anthropology. American Anthropologist 120 (3): 398-411.

Sokona, Y. 2014. IPCC Press Release. IPCC Copenhagen Press Office.

Vance, J. D. 2016. Hillbilly Elegy: A Memoir of a Family and Culture in Crisis. New York: Harper Collins.

West, D. M. and Karsten, J. 2017. Solutions for Global Science Issues Require New Forms of Governance. Brookings Institution. URL: http://brookings.edu/blog/techtank/2017/ 05.04/solutions-for-global-science-require-new-forms-of-governance

Wolf, E. R. 1982. Europe and the Peoples without History. Berkeley: University of California Press. 